\title{
KERAGAMAN VEGETASI PADA AREAL TEPI HUTAN YANG BERBATASAN DENGAN ENCLAVE DI KAWASAN TAMAN NASIONAL BANTIMURUNG BULUSARAUNG
}

\section{DIVERSITY OF VEGETATION IN THE EDGE OF FOREST BORDERING TO ENCLAVE OF BANTIMURUNG BULUSARAUNG NATIONAL PARK}

\author{
Indra A.S.L.P. Putri ${ }^{1 *}$, Bayu Wisnu Broto ${ }^{1}$, Mursidin ${ }^{1}$, Fajri Ansari ${ }^{1}$ \\ ${ }^{1}$ Balai Penelitian dan Pengembangan Lingkungan Hidup dan Kehutanan Makassar, \\ Jalan Perintis Kemerdekaan Km 16.5, Makassar \\ e-mail korespondensi: indra.arsulipp@gmail.com
}

\begin{abstract}
Abstrak
Masyarakat enclave umumnya memiliki tingkat ketergantungan yang tinggi terhadap sumberdaya alam dari kawasan hutan yang terdapat di sekitar tempat tinggal mereka, sehingga aktivitas pemanfaatan tersebut dapat berpengaruh terhadap komunitas tumbuhan di hutan sekitar enclave. Penelitian ini bertujuan untuk mengetahui keragaman vegetasi pada areal tepi hutan yang berbatasan dengan enclave Minggi, yang merupakan enclave yang terdapat di Taman Nasional bantimurung Bulusaraung. Pengamatan vegetasi dilakukan dengan menggunakan metode garis berpetak. Analisis data dilakukan untuk mengetahui nilai kerapatan vegetasi, indeks nilai penting, indeks keragaman hayati Shannon-Weiner, indeks dominansi Simpson, indeks kemerataan Pielou, indeks kekayaan jenis Margalef dan indeks kesamaan komunitas Sorensen. Hasil penelitian memperlihatkan bahwa vegetasi hutan di sekitar enclave Minggi memiliki keragaman vegetasi yang tergolong sedang. Terdapat spesies yang mendominasi, namun nilai indeks dominansinya masih tergolong rendah. Nilai indeks kemerataan jenis vegetasi tergolong rendah, sedangkan nilai indeks kekayaan jenis tergolong tinggi. Kondisi tersebut menunjukkan adanya gangguan atau tekanan oleh masyarakat terhadap hutan. Perubahan kondisi hutan tersebut memerlukan upaya pemulihan kondisi komunitas tumbuhan maupun upaya peningkatan kesadaran dan pembenahan kondisi masyarakat untuk mengurangi tingkat ketergantungan terhadap hutan.
\end{abstract}

Kata kunci: Vegetasi, Tepi hutan, Enclave, Hutan sekunder, Taman Nasional Bantimurung Bulusaraung

\begin{abstract}
Generally, the enclave community owns a high dependency on natural resources surrounding their residence. Their utilization activities affect the plant community in the forest around the enclave. This study aims to determine the diversity of vegetation in the forest edge area bordering to the Minggi enclave, an enclave in Bantimurung Bulusaraung National Park area. Vegetation observation was carried out using the line method. Data analysis was employed to determine the value of vegetation density, important value index, Shannon-Weiner diversity index, Simpson dominance index, Pielou evenness index, Margalef diversity index and Sorensen similarity index. The results showed that the forest vegetation around the Minggi enclave had a moderate diversity of vegetation. The dominant species showed a low value of dominance index. The evenness value of vegetation type is relatively low, while the species richness
\end{abstract}


index is classified as high. These conditions indicate a disturbance or pressure by the enclave community towards the forest. Degraded forest requires efforts to restore the condition of the vegetation as well as efforts to increase awareness and improve wellbeing of community to reduce the level of dependence on the forest.

\section{Key words: Vegetation, Forest edge, Enclave, Secondary forest, Bantimurung Bulusaraung National Park}

\section{Pendahuluan}

Enclave berarti suatu wilayah yang dikelilingi oleh wilayah lain yang berbeda. Enclave merupakan istilah yang pada mulanya digunakan dalam dunia geopolitik. Namun saat ini, penggunaan istilah enclave kemudian berkembang pesat, sehingga istilah enclave telah digunakan di berbagai bidang (Sarmento, 2015). Berdasarkan Peraturan Menteri Kehutanan Nomor P32/Menhut-II/2010, yang dimaksud dengan enclave adalah lahan yang dimiliki oleh perseorangan atau badan hukum di dalam kawasan hutan berdasarkan bukti - bukti yang sah berdasarkan peraturan perundangundangan (Menteri Kehutanan, 2010). Meskipun demikian, di bidang kehutanan, penggunaan istilah enclave lebih ditujukan pada desa yang berada di dalam kawasan konservasi, yang dihuni oleh masyarakat dan ditetapkan sebagai enclave (Perhiptani, 2015).

Enclave Minggi merupakan salah satu enclave yang terdapat di kawasan Taman Nasional Bantimurung Bulusaraung (TN Babul). Qodriyatun (2013) dan Aji et al., (2015) menyatakan bahwa masyarakat sekitar hutan menggantungkan hidupnya dari sumber daya hutan di sekitar mereka. Hutan bahkan menjadi tumpuan ekonomi bagi mereka. Kondisi serupa juga dijumpai pada masyarakat yang bermukim di enclave Minggi. Mayoritas masyarakat yang bermukim di dalam enclave Minggi merupakan petani dan bergantung pada hutan Taman Nasional yang berada di sekitar enclave untuk menopang kehidupan mereka. Selain memanfaatkan berbagai jenis satwa yang dijumpai di dalam hutan, terutama untuk memenuhi kebutuhan protein hewani, maka sumber daya alam hutan yang banyak dimanfaatkan oleh masyarakat enclave Minggi adalah berbagai jenis tumbuhan hutan. Pemanfaatan berbagai jenis tumbuhan hutan tersebut telah berlangsung sejak awal keberadaan masyarakat di tempat tersebut. Berbagai aktivitas pemanfaatan tumbuhan hutan, diduga berpengaruh terhadap komunitas tumbuhan hutan di sekitar enclave Minggi. Penelitian ini bertujuan untuk mengetahui keragaman vegetasi hutan di sekitar enclave Minggi.

\section{Metode Penelitian}

\section{Area penelitian}

Penelitian dilakukan di kawasan hutan dataran rendah non dipterokarpa pamah, yang terletak di sekitar enclave Minggi. Enclave Minggi merupakan sebuah dusun yang terletak di kawasan TN Babul. Secara administrasi, enclave Minggi termasuk dalam wilayah administrasi pemerintahan Desa Tompobulu, Kecamatan Balocci, Kabupaten Pangkajene dan Kepulauan. 


\section{Bahan dan Peralatan}

Peralatan yang digunakan dalam penelitian ini adalah GPS, thermohygrometer, klinometer, parang, pasak, meteran roll, meteran kain, karton manila, kertas roti, kertas koran label gantung, gunting tanaman, alat tulis, tally sheet, kamera, laptop. Bahan yang digunakan dalam penelitian ini adalah berbagai spesies tumbuhan yang dijadikan herbarium, alkohol $70 \%$.

\section{Metode Pengumpulan Data}

Pengumpulan data vegetasi dilakukan melalui pembuatan petak-petak pengamatan yang peletakannya dilakukan secara sistematik dan menggunakan metode garis berpetak (Kusmana, 1997; Mueller-Dombois \& Ellenberg, 1974). Petak pengamatan vegetasi diletakkan memotong kontur atau sungai, dengan jarak antar petak pengamatan adalah 150 - 200 meter. Pengamatan dilakukan pada semua tingkatan tumbuhan mulai dari semai, pancang, tiang hingga pohon. Pengamatan vegetasi pada tingkat pohon dilakukan pada petak berukuran 20 meter x 20 meter. Pengamatan vegetasi pada tingkat tiang dilakukan pada petak berukuran 10 meter $\times 10$ meter. Pengamatan vegetasi pada tingkat pancang dilakukan pada petak berukuran 5 meter $x$ 5 meter. Pengamatan vegetasi pada tingkat semai dan herba dilakukan pada petak berukuran 2 meter $\times 2$ meter. Setiap spesies tumbuhan yang dijumpai di dalam petak pengamatan akan dicatat nama lokal dan jumlah individunya. Untuk tingkat pertumbuhan pancang, tiang dan pohon, juga dilakukan pengukuran diameter batang setinggi dada dan pengukuran tinggi tanaman. Spesies tumbuhan yang belum diketahui nama jenisnya akan diambil bagian tumbuhannya dan dibuat menjadi herbarium, yang selanjutnya dikirim ke Pusat Litbang Biologi LIPI untuk diidentifikasi.

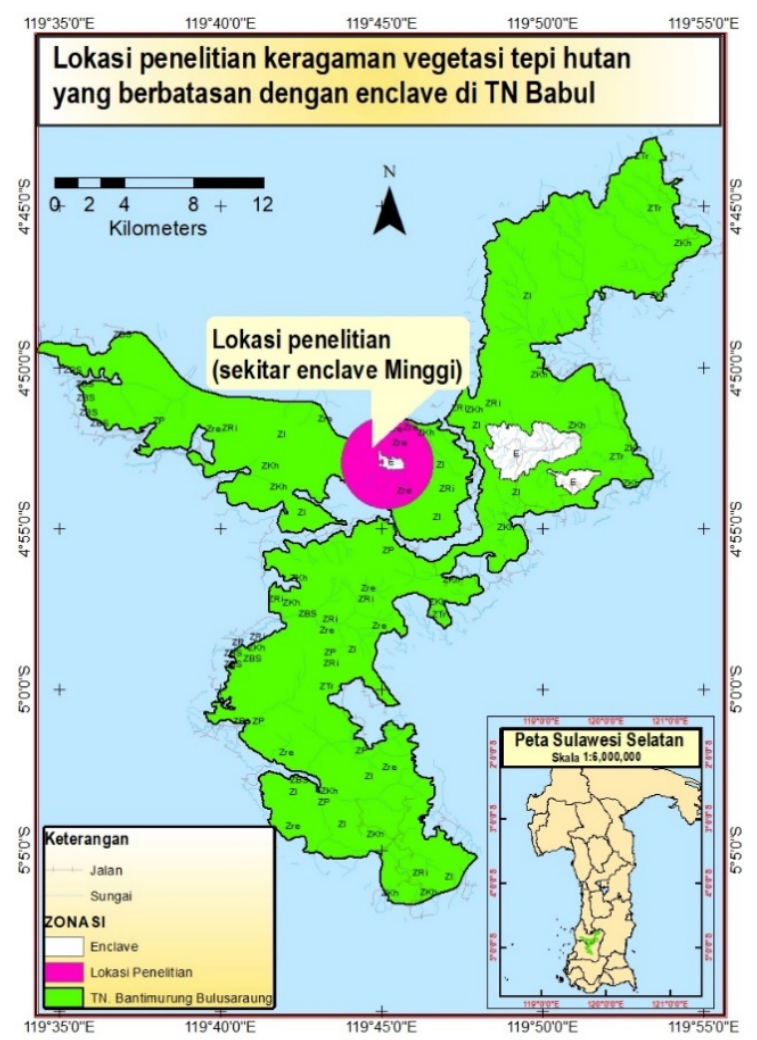

Gambar 1. Peta lokasi penelitian 


\section{Analisis Data}

Analisis data terhadap hasil pengamatan vegetasi dilakukan dengan menghitung nilai kerapatan pada setiap tingkat pertumbuhan (semai, pancang, tiang, pohon). Selain itu juga lakukan analisis dengan menggunakan Indeks Nilai Penting (INP), indeks keragaman jenis Shannon-Weinner $\left(H^{\prime}\right)$, indeks dominansi Simpson (D), indeks kemerataan jenis Pielou (E), indeks kekayaan jenis Margalef $(R)$, serta indeks kesamaan komunitas (IS) (Fachrul, 2012).

\section{Hasil dan Pembahasan}

\section{Hasil}

Hasil pengamatan memperlihatkan bahwa areal hutan di sekitar enclave Minggi dapat dijumpai cukup banyak spesies tumbuhan. Secara keseluruhan di areal hutan sekitar enclave Minggi dapat dijumpai 72 spesies tumbuhan. Deb (2013) menyatakan bahwa tingginya jumlah spesies tumbuhan yang hidup di suatu areal, dapat menunjukkan tingginya keragaman di areal tersebut. Jika ditinjau berdasarkan tingkatan pertumbuhannya, maka pada tingkat semai dan tumbuhan bawah dapat dijumpai 43 spesies tumbuhan. Pada tingkat pancang dapat dijumpai 32 spesies tumbuhan. Pada tingkat tiang dapat dijumpai 24 spesies tumbuhan. Pada tingkat pohon dapat dijumpai 36 spesies tumbuhan.

Komunitas tumbuhan di areal hutan sekitar enclave Minggi tidak memiliki strata vegetasi yang lengkap. Strata vegetasi di areal ini hanya berupa stratum B (pepohonan dengan ketinggian 20 - 30 meter), stratum $C$ (pepohonan dengan ketinggian $4-20$ meter), stratum D (lapisan perdu dan semak dengan ketinggian 1 - 4 meter), dan stratum $\mathrm{E}$ (tumbuhan penutup tanah dengan ketinggian hingga 1 meter). Kerapatan vegetasi di areal ini juga tergolong masih cukup tinggi. Kerapatan vegetasi pada tingkat semai dan tumbuhan bawah adalah 48.906, 25 individu/Ha. Kerapatan pada tingkat pancang adalah 3.125 individu/ $\mathrm{Ha}$. Kerapatan pada tingkat tiang adalah 475 individu/ $\mathrm{Ha}$, sedangkan kerapatan pada tingkat pohon adalah 201,56 individu/Ha. Jika ditinjau dari besarnya nilai indeks nilai pentingnya (INP), maka pada tingkat semai dan tumbuhan bawah, Beilschmieda gemmiflora Blume, Munronia pinnata (Wall.) W. Theob. dan Archidendron pauciflorum I. C. Nielsen., merupakan spesies tumbuhan yang memiliki nilai INP yang tertinggi. Pada tingkat pancang, Munronia pinnata (Wall.) W. Theob., Garcinia treubii Pierre dan Elattostachys zippeliana (Blume) Radlk., merupakan spesies tumbuhan yang memiliki nilai INP tertinggi. Pada tingkat tiang, Rhodomyrtus sp, Garcinia treubii Pierre dan Beilschmieda gemmiflora Blume merupakan spesies tumbuhan yang memiliki nilai INP tertinggi. Pada tingkat pohon, Rhodomyrtus sp, Beilschmieda gemmiflora Blume dan Knema cinerea (Poir.) Warb. merupakan spesies tumbuhan yang memiliki nilai INP tertinggi.

Tabel 1. Spesies tumbuhan dengan Indeks Nilai Penting tertinggi (INP)

\begin{tabular}{ccccc}
\hline No & $\begin{array}{c}\text { Tingkat } \\
\text { Pertumbuhan }\end{array}$ & Nama Lokal & Nama Latin & INP \\
\hline 1 & Semai & Dangang- & Beilschmieda gemmiflora Blume & 29.1 \\
& dangang & & 5 \\
& Lolorupa & Munronia pinnata (Wall.) W. & 23.9 \\
& & Theob & 1 \\
& & Bitontong & Archidendron pauciflorum I.C. & 16.6 \\
2 & Pancang & Maranne & Nielsen & 4 \\
& & Garcinia treubii Pierre & 50.4
\end{tabular}




\begin{tabular}{|c|c|c|c|c|}
\hline \multirow{5}{*}{3} & \multirow{5}{*}{ Tiang } & \multirow{3}{*}{$\begin{array}{l}\text { Bitontong } \\
\text { Lolorupa }\end{array}$} & & 4 \\
\hline & & & Elattostachys zippeliana (Blume) & 32.0 \\
\hline & & & $\begin{array}{c}\text { Munronia pinnata (Wall.) W. } \\
\text { Theob. }\end{array}$ & $\begin{array}{c}28.6 \\
4\end{array}$ \\
\hline & & Maranne & Rhodomyrtus sp & $\begin{array}{c}54.6 \\
7\end{array}$ \\
\hline & & Kirassa & Garcinia treubii Pierre & $\begin{array}{c}29.0 \\
7\end{array}$ \\
\hline \multirow{4}{*}{4} & \multirow{4}{*}{ Pohon } & $\begin{array}{l}\text { Dangang- } \\
\text { dangang }\end{array}$ & Beilschmieda gemmiflora Blume & $\begin{array}{c}19.9 \\
9\end{array}$ \\
\hline & & Maranne & Rhodomyrtus sp. & $\begin{array}{c}45.6 \\
5\end{array}$ \\
\hline & & $\begin{array}{l}\text { Dangang- } \\
\text { dangang }\end{array}$ & Beilschmieda gemmiflora Blume & $\begin{array}{c}43.8 \\
7\end{array}$ \\
\hline & & Pala-pala & Knema cinerea (Poir.) Warb. & $\begin{array}{c}23.4 \\
2\end{array}$ \\
\hline
\end{tabular}

Berdasarkan hasil analisis data terlihat bahwa indeks keragaman vegetasi pada kawasan hutan di sekitar enclave Minggi tergolong sedang, dengan nilai indeks dominansi Simpson yang tergolong rendah. Selain itu, terlihat bahwa komunitas tumbuhan di kawasan hutan sekitar enclave Minggi juga memiliki indeks kemerataan yang tergolong rendah. Hal ini menunjukkan bahwa komunitas tumbuhan pada areal tersebut berada dalam kondisi labil atau tertekan (Fachrul 2012). Meskipun demikian, hasil analisis data memperlihatkan bahwa indeks kekayaan jenis Margalef pada areal hutan yang berada di sekitar enclave Minggi tergolong tinggi. Selain itu, berdasarkan hasil analisis data, terlihat bahwa nilai indeks kesamaan komunitas (IS) pada berbagai tingkat pertumbuhan tergolong cukup tinggi.

Tabel 2. Nilai indeks keragaman hayati Shannon-weiner Simpson (D), kemerataan Pielou (E), kekayaan jenis Margalef (R) dan kesamaan komunitas (IS) di lokasi penelitian

\begin{tabular}{llllll}
\hline \multirow{2}{*}{ No } & \multirow{2}{*}{ Indeks } & \multicolumn{4}{c}{ Tingkat pertumbuhan } \\
\cline { 3 - 6 } & & Semai & Pancang & Tiang & Pohon \\
\hline 1 & Indeks H & 1.41 & 1.30 & 1.10 & 1.35 \\
2 & Indeks D & 0.10 & 0.08 & 0.19 & 1.21 \\
3 & Indeks E & 0.38 & 0.38 & 0.35 & 0.38 \\
4 & Indeks R & 7.31 & 6.42 & 5.29 & 7.20 \\
5 & Indeks IS & semai-pancang & 53.33 & \\
& & semai-tiang & 41.79 & \\
& & semai-pohon & 30.38 & \\
& & pancang-tiang & 57.14 & \\
& & pancang-pohon & 44.12 & \\
& & tiang-pohon & 53.33 & \\
\hline
\end{tabular}




\section{Pembahasan}

\section{Keragaman, struktur dan komposisi hutan yang berbatasan dengan enclave}

Kawasan hutan yang berada di dekat pemukiman penduduk umumnya mengalami tekanan. Hal ini juga dijumpai di kawasan hutan yang mengelilingi enclave. Salah satu contoh mengenai adanya tekanan masyarakat terhadap kawasan hutan yang berada di sekitar enclave dikemukakan oleh Saputra (2014), yang menyatakan bahwa kondisi kawasan hutan di sekitar enclave Singkati Batanghari mengalami tekanan dan penurunan akibat berbagai aktivitas masyarakat. Hal serupa juga dijumpai pada komunitas tumbuhan di tepi hutan enclave Minggi, yang terlihat mengalami tekanan akibat aktivitas masyarakat. Meskipun demikian, jika melihat nilai indeks kesamaan komunitas, maka tekanan tersebut belum sampai pada tahap merubah komposisi komunitas tumbuhan. Jika merunut pada sejarah pengelolaan, tekanan terhadap komunitas tumbuhan di sekitar kawasan enclave sebenarnya telah terjadi jauh sebelum areal tersebut ditetapkan menjadi kawasan taman nasional. Areal hutan di sekitar enclave Minggi, telah terlebih dahulu dirambah atau dimanfaatkan sumber dayanya oleh masyarakat pada beberapa dekade sebelumnya. Cukup tingginya intensitas pemanfaatan sumber daya hutan di sekitar enclave, dapat disebabkan karena kondisi masyarakat enclave yang terbatas. Bentuk keterbatasan mayarakat yang bermukim di enclave Minggi diantaranya adalah keterbatasan aksesibilitas.

Masyarakat enclave Minggi bermukim di tengah hutan, yang tergolong cukup sulit untuk dijangkau. Jarak enclave yang jauh dari jalan raya serta dari desa lainnya, ditambah dengan sarana jalan yang menuju dan keluar dari enclave yang kondisinya kurang memadai, menghambat perkembangan ekonomi masyarakat enclave Minggi, sehingga mayoritas masyarakat enclave memiliki tingkat penghasilan yang rendah. Bentuk keterbatasan lain adalah rendahnya tingkat pendidikan masyarakat. Hal ini menyebabkan rendahnya pola pikir dan kemampuan masyarakat untuk berinovasi, atau mencari cara lain, untuk memenuhi dan meningkatkan taraf hidup. Akibatnya, masyarakat enclave Minggi hanya mengandalkan kekayaan hutan di sekitar enclave untuk memenuhi kebutuhan hidup. Misalnya, pemanfaaatan hasil hutan bukan kayu yang berasal dari hewan seperti madu, maupun berbagai jenis burung untuk menambah asupan protein hewani. Masyarakat enclave Minggi juga memanfaatkan hasil hutan bukan kayu yang berasal dari tumbuh - tumbuhan, seperti umbi - umbian hutan, buah - bahan dari hutan, dedaunan, nira aren untuk dibuat menjadi gula dan minuman tradisional, serta pemanfaatan berbagai jenis tumbuhan sebagai bahan obatobatan.

Hal lain yang memperlihatkan tingginya tingkat ketergantungan masyarakat enclave Minggi terhadap sumber daya hutan adalah adanya pemanfaatan beberapa spesies tumbuhan yang diketahui mempunyai kualitas yang baik sebagai kayu pertukangan. Spesies tumbuhan tersebut, apabila telah mencapai diameter yang cukup, akan dimanfaatkan oleh masyarakat sebagai bahan konstruksi bangunan rumah. Pemanfaatan berbagai spesies tumbuhan berukuran dan berdiameter besar tersebut, diduga menjadi penyebab tertekannya komunitas tumbuhan di areal sekitar enclave, sehingga tidak dijumpai pepohonan yang tingginya diatas 30 meter. Selain itu, pemanfaatan spesies tumbuhan tertentu yang kayunya disukai oleh masyarakat, juga diduga menjadi penyebab sehingga jenis-jenis tumbuhan yang memiliki nilai INP tertinggi merupakan jenis tumbuhan yang kurang disukai oleh masyarakat untuk dimanfaatkan kayunya. Jenis-jenis tumbuhan yang memiliki kualitas kayu yang baik, seperti Diospyros sp., hanya dijumpai dalam jumlah yang sangat sedikit dan dengan diameter yang kecil. 
Selain memanfaatkan berbagai spesies tumbuhan yang memiliki kualitas kayu yang baik, masyarakat enclave juga memanfaatkan berbagai spesies tumbuhan sebagai kayu bakar, baik untuk memasak makanan sehari-hari, maupun sebagai bahan bakar dalam pembuatan gula aren. Berbagai bentuk pemanfaatan tumbuhan tersebut diduga menjadi penyebab tertekannya kondisi komunitas tumbuhan di areal hutan yang berbatasan dengan enclave, sehingga nilai indeks keragaman hayati di areal hutan tersebut nilainya hampir mendekati nilai rendah.

Bentuk gangguan lain terhadap komunitas tumbuhan di areal hutan yang berbatasan dengan enclave adalah dibukanya beberapa lokasi areal hutan di sekitar enclave, untuk dijadikan sebagai kebun. Pembukaan kebun tersebut telah terjadi pada kurun waktu puluhan tahun lalu. Saat ini, areal bekas kebun tersebut telah ditinggalkan oleh masyarakat dan dibiarkan menjadi hutan kembali. Namun areal bekas kebun tersebut masih dapat dikenali dari dijumpainya jenis-jenis tumbuhan yang umum dibudidayakan masyarakat, seperti jambu air (Eugenia sp). Satu hal yang menjadi perhatian adalah meskipun areal bekas kebun di sekitar enclave Minggi telah cukup lama ditinggalkan dan sedang dalam proses suksesi alami yang terlihat dari struktur komunitas tumbuhan penyusunnya yang telah membentuk kurva $\mathrm{J}$, namun, dengan melihat nilai dari berbagai parameter penguji yang digunakan untuk mengetahui kondisi komunitas tumbuhan, terlihat bahwa areal tersebut masih belum pulih, sehingga areal tersebut masih tetap perlu untuk mendapat perhatian agar tidak lagi mengalami gangguan lain.

\section{Implikasi Konservasi}

Kondisi labil dan tertekan yang diperlihatkan oleh komunitas tumbuhan yang hidup di sekitar enclave Minggi perlu mendapatkan perhatian yang serius dari pengelola TN Babul. Pemulihan kondisi hutan dapat dilakukan misalnya dengan kegiatan rehabilitasi hutan. Selain itu, mengingat banyaknya pemanfaatan kayu yang berasal dari jenis-jenis pohon tertentu, maka sebaiknya pihak pengelola dapat mengupayakan bantuan penanaman jenis - jenis pohon yang kayunya disukai oleh masyarakat di dalam areal enclave. Hal ini dilakukan dengan melibatkan masyarakat untuk menjaga dan memelihara pepohonan tersebut, dengan jaminan pemanenan dikemudian hari, untuk mengurangi pemanfatan kayu dari dalam kawasan hutan taman nasional. Perhatian juga harus diberikan kepada masyarakat yang tinggal di enclave Minggi. Masyarakat enclave Minggi yang memiliki tingkat ekonomi tergolong rendah dan mempunyai ketergantungan yang tinggi terhadap sumber daya hutan, merupakan subyek yang sebaiknya dibenahi terlebih dahulu. Pembenahan masyarakat tersebut dilakukan untuk mengurangi kegiatan destruktif terhadap hutan dan sekaligus mengurangi tingkat ketergantungan terhadap sumber daya hutan. Berbagai langkah yang dapat dilakukan, misalnya melalui pemberdayaan masyarakat, maupun pendampingan yang melibatkan berbagai stakeholder untuk membuka wawasan masyarakat. Bentuk kegiatan lain yang dapat dilakukan adalah dengan meningkatkan peran hasil hutan bukan kayu, yang tidak bersifat destruktif dibanding pemanfaatan hasil hutan kayu, dalam perekonomian masyarakat enclave. Selain itu, pihak TN Babul juga dapat mengupayakan peningkatan pengetahuan dan kesadaran masyarakat akan pentingnya menjaga kelestarian kawasan hutan melalui penyuluhan, atau kegiatan yang berkaitan dengan konservasi, pendidikan cinta lingkungan, disamping mulai melaksanakan penegakan hukum bagi para perambah atau perusak hutan. 


\section{Kesimpulan}

Areal hutan di sekitar enclave Minggi memiliki keragaman vegetasi yang tergolong sedang. Meskipun terdapat spesies yang mendominasi, namun nilai indeks dominansi masih tergolong rendah. Areal ini juga mempunyai nilai indeks kemerataan jenis yang tergolong rendah dan indeks kekayaan jenis yang tergolong tinggi. Kondisi tersebut menunjukkan adanya gangguan atau tekanan oleh masyarakat. Adanya tekanan masyarakat terhadap hutan menyebabkan perlunya upaya pemulihan kondisi komunitas tumbuhan maupun upaya pembenahan kondisi masyarakat untuk mengurangi tingkat ketergantungan terhadap hutan.

\section{Daftar Pustaka}

Aji, G. B., Yuliyanti, R., Suryanto, J., Ekaputri, A. D., Saptono, T., \& Muis, H. (2015). Sumbangan Hutan Kemasyarakatan dan Hutan Desa terhadap Pendapatan dan Pengurangan Kemiskinan: Studi Kasus. Jakarta: Pusat Penelitian Kependudukan LIPI dan Kemitraan bagi Pembaruan Tata Pemerintahan di Indonesia.

Deb, D. (2013). Toward Sustainable Use of Forest Resource: Connecting Forest Ecology to Village Economy. Bhubaneswar, India: Regional Centre for Development Cooperation (RCDC).

Fachrul, M. F. (2012). Metode Sampling Bioekologi (First ed. Vol. 1). Jakarta, Indonesia: Bumi Aksara.

Kusmana, C. (1997). Metode Survey Vegetasi. Bogor: PT. Penerbit Institut Pertanian Bogor.

Menteri Kehutanan. (2010). Peraturan Menteri Kehutanan Nomor P32/Menhut-II/2010 Tentang Tukar Menukar Kawasan Hutan. Jakarta: Kementerian Kehutanan. Mueller-Dombois, D., \& Ellenberg, H. (1974). Aims and methods of vegetation ecology. New York, United States: John Wiley \& Sons

Perhiptani. (2015). Program Swasembada Pangan Perlu Pendampingan Penyuluh. Retrieved from http://perhiptani.org/berita-239-.html (akses 26 Juni 2019)

Qodriyatun, S. N. (2013). Pengentasan Kemiskinan Masyarakat Sekitar Hutan Konservasi: Studi Pemberdayaan Masyarakat Melalui Model Desa Konservasi $(\mathrm{H}$. Retnaningsih Ed.). Jakarta: Pusat Pengkajian, Pengolahan Data dan Informasi (P3DI) Sekretariat Jenderal DPR Republik Indonesia bersama Azza Grafika.

Saputra, Y. (2014). Valuasi Ekonomi Lingkungan Alih Fungsi Lahan pada Kawasan Hutan Eks-Areal HPH: Studi Kasus pada Kawasan Hutan Enclave Singkati Batanghari Desa Semambu Kecamatan Sumay Kabupaten Tebo Provinsi Jambi. (Doktoral Disertasi), Universitas Gadjah Mada, Yogyakarta.

Sarmento, J. C. V. (2015). Enclaves. In C. Cater, B. Garrod, \& T. Low (Eds.), The Encyclopedia of Sustainable Tourism. Oxford, United Kingdom: CABI. 